\title{
Tasa-arvo aikuiskasvatuksessa
}

Aikuiskoulutuksen johtoryhmä julkaisi viime keväänä muistion tasa-arvosta aikuiskoulutuksen suunnittelun lähtökohtana. Muistio on käynnistänyt keskustelun yleensä tasaarvosta aikuiskasvatuksessa. Kansanvalistusseura ja Aikuiskasvatuksen Tutkimusseura järjestivät 1.11.1982 Helsingissä keskustelutilaisuuden "Tasa-arvo aikuiskasvatuksessa". Tilaisuuteen osallistui kolmisenkymmentä aikuiskasvatuksen eri aloilla työskentelevää henkilöä. Pyydetyt puheenvuorot käyttivät tilaisuudessa toiminnanjohtaja Timo Toiviainen, joka toimii johtoryhmän sihteerinä, dosentti Aulis Alanen Tampereen yliopistosta sekä Anita Haataja tasa-arvoasiain neuvottelukunnasta. Toiviainen puhui tasa-arvosta aikuiskoulutuksen suunnittelussa, Alanen vapaudesta ja tasa-arvosta aikuiskasvatuksessa ja Haa-

\section{Urpo Harva}

\section{Tasa-arvo ja kasvatus}

\section{Kasvatus ja koulutus}

Kasvatus sisältää mm. koti-, koulu- ja korkeakoulukasvatuksen sekä aikuiskasvatuksen. Ne kuuluvat kasvatusjärjestelmään .

Koulutusta harjoittaa koulujärjestelmä (peruskoulu, lukio ja ammatilliset koulut) sekä korkeakoululaitos. Ne muodostavat yhdessä koulutusjärjestelmän. Siihen kuuluvat myös jonkin formaalisen pätevyyden tuottavat kurssit.

Aikuiskasvatusta suorittavat vapaa sivistystyö, avoin yliopisto ja formaaliseen pätevyyteen tähtäävä aikuiskoulutus, johon avoin yliopisto kuuluu silloin, kun tähdätään arvosanojen suorittamiseen.

On jyrkästi vastustettava sellaista koulutussanan väärinkäyttöä, josta esimerkkinä on ai- taja sukupuolten yhdenvertaisuuden toteutumisesta käytännössä.

Opetusministeriön tasa-arvotyöryhmä järjesti 7.12. lähinnä sukupuolten tasa-arvoa ja osallistumista aikuiskoulutuksessa käsittelevän seminaarin. Seminaariin osallistui noin sata henkilöä.

Keskustelu tasa-arvosta jatkuu edelleen. Mm. professori Urpo Harva, ja nimimerkki Andragogi tuovat tämän numeron artikkeleissa esiin ajatuksiaan siitä. Koska koko aikuiskasvatuksen suunnittelu tulisi periaatepäätöksen mukaan pohjautua tasa-arvoajattelulle, niin keskustelu ei totisesti ole käynnistynyt liian aikaisin. Päätöshän annettiin jo vuonna 1978. Toivottavasti keskustelu täsmentää ainakin joiltakin osin käsityksiämme yleensä tasa-arvosta ja sen käyttömahdollisuuksista aikuiskasvatuksen suunnittelussa. kuiskoulutuksen johtoryhmän mietintö Tasaarvo aikuiskoulutuksen suunnittelun periaatteena. Muuten ruvetaan kai puhumaan itsekoulutuksesta ja persoonallisuuden koulutuksesta sekä koulutustieteestä. Prof. Seppo Randell valitti minulle, että koulutus-sanan väärinkäyttö on tunkeutunut jo yliopistoonkin.

Vapaa sivistystyö ei siis ole koulutusta eikä kuulu koulutusjärjestelmään, mutta formaaliseen pätevyyteen tähtäävä aikuiskoulutus kuuluu siihen.

- Koulutus sisältyy kasvatukseen. Puhumme kasvatuksesta silloin kun ajattelemme persoonallisuuden kehittämistä (esim. opettajien kasvatus) ja koulutuksesta silloin, kun ajattelemme muodolliseen pätevyyteen tähtäävää opetusta (esim. opettajien koulutus). 


\section{Tasa-arvo}

Aristoteleen mukaan ihmisten tasa-arvoa eli tasa-arvoisuutta, samanarvoisuutta, tasavertaisuutta (égalité, equality, Gleichheit, jämlikhet) ei tarvitse perustella (eikä sitä voisikaan). Sen sijaan ihmisten eriarvoinen kohtelu pitää perustella. Aristoteles ei siis hyväksy tasa-arvoisuutta yleispäteväksi normiksi.

Näin ei tee myöskään Ranskan vallankumouksen ihmisoikeuksien julistus. Sen mukaan tasa-arvoisuudesta on pidettävä kiinni mikäli yhteishyvä (bonum commune) ei toisin vaadi. Myöskään marxismi ei pidä tasa-arvoisuutta yleispätevänä normina.

Aristoteles erottaa formaalisen ja proportionaalisen tasa-arvon. Edellinen ei kiinnitä huomiota ihmisten ja heidän yhteiskunnallisen asemansa erilaisuuteen. Toteutettaessa proportionaalista tasa-arvoa on jokaiselle annettava hänen oman mittansa mukaan. Ei saa käsitellä erilaisia samanlaisina eikä samanlaisia erilaisina. Formaalinen tasa-arvo vaatii, että kaikille annetaan housut, mutta proportionaalisen tasa-arvon mukaan suurikokoisille on annettava suuremmat housut kuin pienikokoisille (Tasa-arvoa olen käsitellyt kirjassani Ihminen hyvinvointivaltiossa, 1964).

Egalitarismi pyrkii vain formaaliseen tasaarvoon eli samanlaisuuteen, tasapäisyyteen.

\section{Tasa-arvon määritelmiä}

Vuoden 1971 koulutuskomitean mukaan tasa-arvon lisääminen tarkoittaa koulutuserojen pienentämistä. Tasa-arvo toteutuisi siis vasta sitten kun kaikki tulisivat tohtoriksi.

Komitea tarkoittaa tasa-arvolla myös samanlaisia mahdollisuuksia koulutukseen osallistumiseen. Sen saavuttamiseksi on luotava $\mathrm{mm}$. alueellinen tasa-arvoisuus eli osallistumisen maantieteelliset esteet on poistettava. On kai siis esim. perustettava joka pitäjään yliopisto.

Johtoryhmän mukaan tasa-arvoehtona perus- ja keskiasteen koulutuksessa on, että käytännöllisesti katsoen oppimistulokset ovat samat kaikilla tietyn perusjoukon yksilöillä. Tasa-arvoon siis päästään kun kaikille oppilaille annetaan kaikissa aineissa sama numero (viitonen vaiko kymppi?).

Näiden egalitarististen koulutuksellisen tasaarvon määritelmien mukaan tasa-arvo on mahdoton saavuttaa. Jo tehokas pyrkimys tasa-arvoon johtaisi mielettömyyksiin.

Sen sijaan kohtuullinen pyrkimys esim. oppimisvaikeuksien voittamiseen ja huono-osaisten auttamiseen on mielekästä. Kun kuitenkin resurssit ovat rajalliset, on vaarana se, että hyvälahjaisten ja hyväosaisten oppimismahdollisuuksia kavennetaan, mikä saattaa olla haitaksi yhteishyvälle.

Tasa-arvo on määritelty myös samanlaiseksi pääsymahdollisuudeksi koulutukseen. Tämä onkin toteutunut peruskoulun kohdalla. Tasokurssien poistamisen jälkeen kaikilla on myös formaalinen mahdollisuus päästä lukioon, muttei reaalisia mahdollisuuksia, koska pyrkijät seulotaan. Myös korkeakoulut suorittavat opiskelijavalintaa.

Voiko valikointi tapahtua tasa-arvoa loukkaamatta?

On sanottu, että valikointi tai valikoituminen tapahtuu tasavertaisesti silloin, kun lukiossa ja korkeakouluissa opiskelee suhteellisesti yhtä paljon eri yhteiskuntaryhmistä ja eri alueilta olevia. Vinoutumat eivät kuitenkaan johdu enää paljoakaan opiskeluun pääsyn esteistä, esim. köyhyydestä, vaan siitä, että eri ryhmät arvostavat opiskelua eri tavoin. Näin ollen ei olisi mielekästä pyrkiä tasavertaiseen valikoitumiseen.

Egalitaristit ovat tehneet ylioppilastutkinnon jokseenkin samanlaiseksi kaikille, jotta se antaisi samanlaiset pääsymahdollisuudet korkeakouluihin. Tämä on kuitenkin vienyt alueelliseen eriarvoisuuteen siten, että pohjoissuomalaisten ylioppilaiden arvosanat ovat huonommat kuin eteläsuomalaisten, koska tutkinnon sisältö motivoi edellisiä heikommin heidän erilaisen sosiokulttuurisen taustansa takia.

Kun tasa-arvon nimissä koulutus suunnitellaan samanlaiseksi kaikille riippumatta koulutettavien taustasta ja arvojärjestelmästä, tulee suunnittelun pohjaksi huomaamatta suunnittelijoiden oma arvojärjestelmä.

Kasvatuksellisella tasa-arvoisuudella tarkoitetaan muun muassa, että kaikki saavuttavat samalla tavalla esim. koulun kasvatustavoitteet, joten kaikilla on esim. samanlaiset edellytykset itsensätoteuttamiseen ja monimuotoiseen osallistumiseen. Tällainen pyrkimys persoonallisuuksien valamiseen samassa muotissa on sekä mahdotonta että mieletöntä.

Sivistyksellisellä tasa-arvoisuudella tarkoitetaan tavallisesti, että sivistymisen mahdollisuudet jakaantuvat tasaisesti yksilöiden, ryhmien ja alueiden kohdalla. Tämä ei ole mahdollista eikä siihen mielestäni tule pyrkiäkään. Yksilön, ryhmän ja alueen sivistyksen pitää olla omaleimaista. Kehitettäessä sivistymisen mahdollisuuksia (kulttuuria) on omaleimaisuus otettava huomioon.

Samanlaisia asioita on pakko pitää samanarvoisina, mutta voimme pitää samanarvoisina 
myös erilaisia asioita. Egalitarismi pitää kuitenkin erilaisia asioita eriarvoisina. Se ei pidä esim. talonpoikais- ja työläiskulttuuria tasa-arvoisina. Siksi kulttuuri ja sivistys pitää samanlaistaa. On helpompi suunnitella ja hallita yhdenmukaista koulutus- ja kulttuuripolitiikkaa. Sen avulla voidaan myös eliminoida vaaralliset toisinajattelevat.

Näistä syistä halutaan myös aikuiskasvatus käsittää koulutukseksi ja tehdä koulutusjärjestelmän osaksi.

\section{Itsensätodellistaminen}

Tasa-arvo määritellään myös sanomalla, että jokaisella pitää olla mahdollisuus itsensätodellistamiseen. Tämä määritelmä vie ristiriitaan kaikkien egalitarististen tasa-arvomääritelmien kanssa paitsi sen, että kaikkien pitää päästä peruskouluun. Jos siitä pidetään kiinni, on tasokurssit tai jokin vastaava opetuksen eriyttäminen säilytettävä, mikä merkitsee erivertaisuutta oppimistuloksissa ja pääsyssä lukioon ja korkeakouluihin.

Viimeaikaisten mietintöjen sekavuus ja ristiriitaisuus johtuu siitä, että niissä yritetään yhdistää vesi ja tuli: samanlaisuus ja itsensätodellistaminen. Siksi myös tasa-arvon määrittely koetaan vaikeaksi.

\section{Yhteishyvä}

Siitä, minkälaiseksi yhteishyvä eli yhteiskunnan arvojärjestelmä käsitetään, riippuu, miten tasa-arvo toteutuu elämän eri aloilla.

Jos esim. katsotaan, että loistavat urheilusaavutukset kuuluvat kansakunnan yhteishyvään, on ilmeistä, että urheilullisten valioyksilöiden kasvatukseen jo koulussa pannaan suuri paino, kuten tapahtuu Itä-Saksassa.

Itäsaksalaiset, kuten muutkin marxilaiset selittävät, että tasa-arvo on abstraktinen prinsiippi, joka ei ole yleispätevä. Siinä konkreettisessa tilanteessa, jossa sosialistiset maat nyt ovat, tasa-arvoa ei pidä soveltaa kasvatukseen. Sosialismin rakentamiseksi tarvitaan myös sellaisia kouluja, jotka ovat huippulahjakkaita varten. Sosialismin rakentaminen on korkeampi arvo kuin tasa-arvo.

\section{Yhteiskunnan \\ tasa-arvoistaminen}

Sanotaan, että koulutuksen tavoitteet pitää johtaa yhteiskuntapolitiikan tavoitteista. Eräs yhteiskuntapolitiikan tavoite on taloudellinen tasa-arvoisuus.

Keskeinen talouspolitiikan tavoite on nyt taloudellinen kasvu ja kansainvälisen kilpailukyvyn turvaaminen. Näistä tavoitteista seuraa kuitenkin erivertaisuutta, nimittäin suuret tuloerot ja työttömyys. Tuloerot näyttävät välttämättömiltä kasvuun pyrittäessä.

Sangen yleinen on sellainen kuvitelma, että koulutuksellisesta tasa-arvoisuudesta seuraa taloudellinen tasa-arvoisuus. Jo arkikokemus osoittaa tämän harhaksi. Esim. kaikki akateemisen tutkinnon suorittaneet eivät ole likimainkaan samalla tulotasolla. Chistopher Jencks on osoittanut, että tasavertaiset mahdollisuudet koulutukseen eivät tuota taloudellista tasavertaisuutta (Inequality, 1972, New York). Tuloerot riippuvat monista seikoista, joita koulutus ei pysty poistamaan.

\section{Tarpeet}

Johtoryhmän mukaan deprivoituneet ihmiset on tasa-arvon tähden saatava mukaan koulutukseen. Tämä edellyttää, että on lähdettävä heidän koetuista koulutustarpeistaan tai ellei sellaisia ole, ne on herätettävä tai luotava.

Ammatillinen koulutus edistää yksilön tasaarvoistumista. Siksi tarve siihen on herätettävä, päättelee johtoryhmä.

(Aikuis)kasvatuksen teorian ja myös tasaarvo-ongelman keskeisiä käsitteitä on tarve (koulutus-, sivistystarve). Mikä on koettu ja tiedostamaton, oikea ja väärä (vääristynyt, vieraantunut), aito ja keinotekoinen tarve? Voidaanko tarpeita luoda? Kuka niitä luo? Onko kaikilla samat aidot tarpeet? Saavatko mainonnan, kapitalistisen yhteiskunnan, luomat tarpeet aikaan eriarvoisuutta?

Tässä on tyydyttävä vain mainitsemaan, että eräät nykymarxilaiset ovat rakentamassa valaisevaa tarveteoriaa. 